\title{
PRODUCTION SCHEDULING HEURISTICS FOR FREQUENT LOAD-SHEDDING SCENARIOS: A KNOWLEDGE ENGINEERING APPROACH
}

\author{
M.T. Dewa ${ }^{1 *}$, A.F. van der Merwe ${ }^{2} \&$ S. Matope ${ }^{2}$
}

\section{ARTICLE INFO}

\section{Article details}

Presented at the $31^{\text {st }}$ annual conference of the Southern African Institute for Industrial Engineering (SAllE), held virtually from 5-7 October 2020 .

Available online $\quad 11$ Nov 2020

\section{Contact details}

* Corresponding author mncedisi.dewa@wits.ac.za

Author affiliations

1 School of Mechanical, Aeronautical and Industrial Engineering, University of the Witwatersrand, South Africa

2 Department of Industrial Engineering, University of Stellenbosch, South Africa

ORCID ${ }^{\circledR}$ identifiers

M.T. Dewa

https: //orcid.org/0000-0002-5021-8097

A.F. van der Merwe

https: / /orcid.org/0000-0002-0688-1254

S. Matope

https://orcid.org/0000-0001-5598-1027

\section{DOI}

http://dx.doi.org/10.7166/31-3-2422

\section{ABSTRACT}

Most industrial machinery and equipment used by the South African manufacturing sector is powered by either a direct current or an alternating current electricity supply. With the recent frequent power cuts caused by load shedding, operations managers have a difficult time trying to satisfy demand. Power cuts are a supplier-related operational disturbance that leads to production halts, increased downtime, and a significant compromise in delivery due date conformance. The paper presents heuristic rules of thumb that can be applied during the process planning and scheduling of orders during cases of frequent load shedding to maintain high levels of system reliability and productivity. Different load shedding scenarios are characterised, and an appropriate strategy for production planning and scheduling is outlined for each scenario. A knowledge engineering approach is employed in the study, with expert opinions derived from surveys and the literature employed to generate the strategies. These strategies are validated through a simulation study conducted in a small manufacturing firm.

\section{OPSOMMING}

Die meeste industriële masjinerie en toerusting wat in die Suid-Afrikaanse vervaardigingsektor gebruik word, word aangedryf deur 'n gelykstroom- of wisselstroomtoevoer. Met die onlangse gereelde kragonderbrekings wat veroorsaak word deur beurtkrag, is dit moeilik vir operasionele bestuurders om aan die vraag te voldoen. Kragonderbrekings is 'n bedryfsversteuring wat met die verskaffer verband hou, wat lei tot stilstand in die produksie, verhoogde stilstandtyd en ' $n$ aansienlike kompromie ten opsigte van die afleweringsdatum. Die artikel bevat heuristiese reëls wat toegepas kan word tydens die beplanning en skedulering van bestellings tydens gevalle van gereelde beurtkrag om die stelsel se betroubaarheid en produktiwiteit te handhaaf. Verskillende scenario's vir beurtkrag word gekenmerk, en 'n gepaste strategie vir produksiebeplanning en -skedulering word vir elke scenario uiteengesit. ' $n$ Kennisingenieurswese-benadering word in die studie toegepas, met kundige opinies afgelei van opnames en die literatuur wat gebruik word om die strategieë te genereer. Hierdie strategieë word bekragtig deur middel van ' $n$ simulasie-studie wat in 'n klein vervaardigingsonderneming gedoen is.

\section{INTRODUCTION}

The availability of electricity is one of the drivers of the productive activities that sustain economic growth in a nation. In South Africa, Eskom is the main national parastatal supplier of electricity responsible for generating and distributing electrical energy. In 2014, reports from Statistics South Africa [1] revealed that Eskom generated 95 per cent of South Africa's electricity. However, owing to maintenance backlogs, skills shortages, and challenges in securing coal, the power generated by Eskom has declined in recent years (Figure 1), resulting in electricity demand surpassing current supply. This downward trend is continuing. To avoid a power system failure on the national grid, Eskom has resorted to frequent load-shedding schedules as the last resort, leaving many local businesses in a power crisis. According to Van der Nest [2], load 
shedding involves planned rolling blackouts on a rotating schedule throughout the country to avoid a situation of total system failure.

When load shedding occurs, manufacturing operations are shut down, resulting in increased downtime, decreased productivity and, at times, equipment damage. A majority of manufacturers still lack enough working capital for them to purchase or hire back-up generators. For such small businesses, investing in alternative power sources is also an uphill task owing to the limited income they generate. As a result, when power cuts occur, customer orders may be delayed owing to interruptions to scheduled tasks that require electrical power. With the increased frequency of load shedding since the autumn of 2014, South African manufacturers have had no choice but to plan their production by considering power cuts as another constraint. With the prior knowledge of a planned upcoming load shedding schedule, operations managers can prepare their order schedules in a predictive manner.

The paper presents heuristic rules for order sequencing that manufacturers can use during their process planning and scheduling to maintain their delivery responsiveness and high levels of system availability for customer satisfaction. Different stages of load shedding are outlined and, depending on the timing of the power cut, an appropriate strategy is proposed. A simulation study was conducted to validate the results of the study. The paper is structured as follows: first, the impact of load shedding is outlined; second, different approaches to production scheduling with disturbances are explored from the literature; third, we present the case study, the data collection methodology adopted; and finally, the results of the study are used to suggest a rescheduling policy strategy that enables manufacturers in South Africa to plan their work in cases of load shedding.
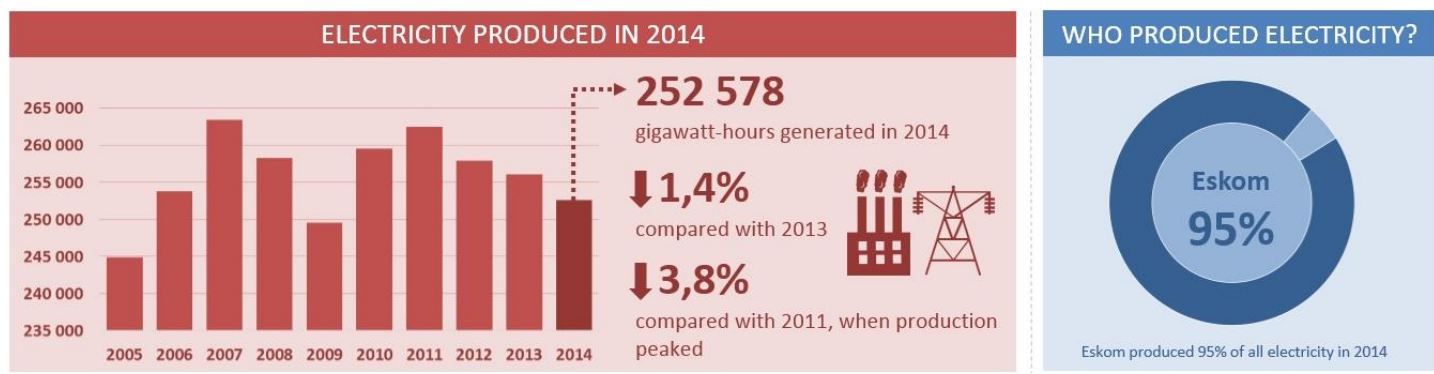

Figure 1: Trends in electricity generated and consumed, 2005-2014 [1]

Responding optimally in times of unexpected change requires expertise and skill. In most cases, the required knowledge or skills in such scenarios can be obtained from human experts and translated into computerised models and algorithms. The knowledge engineering approach involves consultation with human experts to gain understanding of how to solve problems in complex situations (before expert system development) [3]. Expert opinions on what South African manufacturers running small businesses can do to be productive during periods of power cuts are also provided in the study.

\section{LITERATURE REVIEW}

\subsection{Load shedding's impact on manufacturing operations}

Research has revealed that the electricity-intensive industries are the main contributors to economic growth in many nations [4], [5], [6]. The manufacturing sector in South Africa is one of the main contributors to the gross domestic product (GDP). In 2013 alone, the manufacturing sector contributed 15.4 per cent to GDP, and was ranked the second sector contributing to economic growth, as shown in Figure 2 [7]. According to Davidson and Winkler [8], various activities in manufacturing operations in South Africa are energyintensive, and depend heavily on the power supply. 


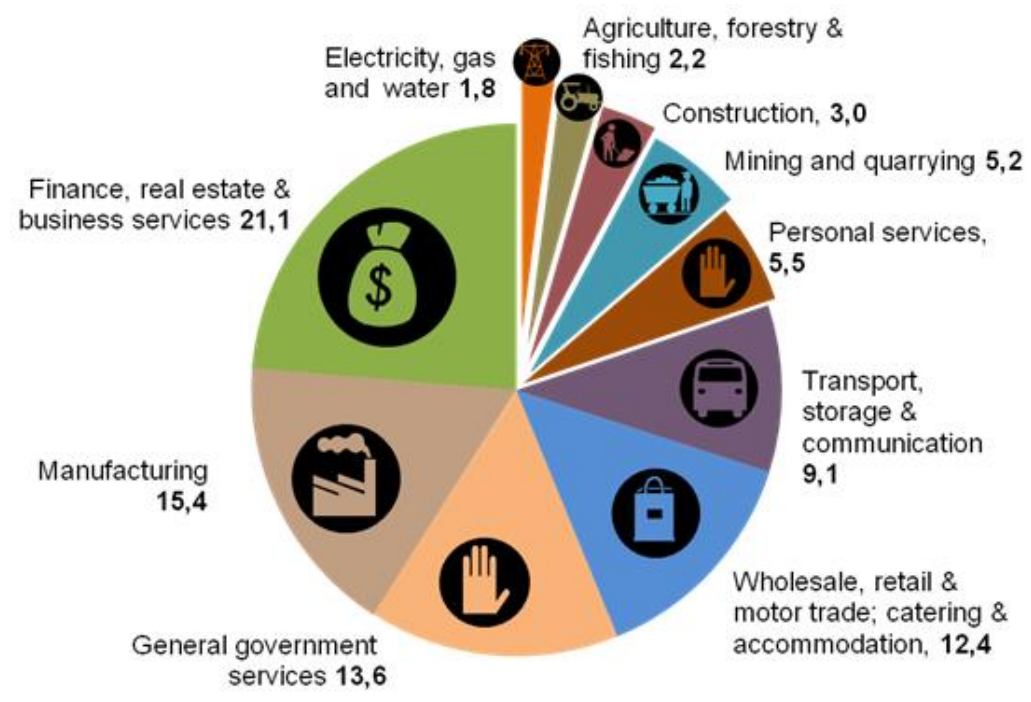

Figure 2: Contributors to South African GDP [7]

The South African manufacturing sector alone consumes about 46 per cent of the power generated by Eskom - the highest consumer of generated power, as shown in Figure 3 [9]. This means that the manufacturing sector in South Africa is the most affected sector when load shedding occurs. Eskom has defined four load shedding stages. Stage 1 power cuts allow for up to one thousand megawatts (1000MW) of electricity load to be shed from the national grid. Likewise, two thousand megawatts $(2000 \mathrm{MW})$ are shed for Stage 2 power cuts, while four thousand (4000MW) and eight thousand megawatts $(8000 \mathrm{MW})$ of electricity are shed for Stages 3 and 4 power cuts respectively. The power cuts are usually implemented for two-hour blocks, with an additional thirty minutes of changing from one block to the next.

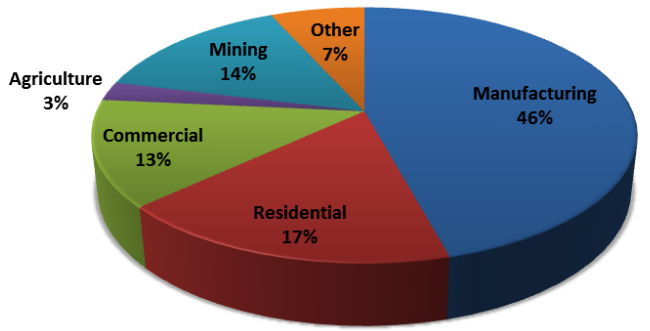

Figure 3: Electricity consumption per sector in South Africa [9]

When a power cut is implemented, a production line can be shut down and customer order processing can be delayed. With prior knowledge of an upcoming power cut, load shedding has become a predictable supplier-related operational disturbance that no manufacturer can ignore. Production planning and scheduling becomes a challenge, since most manufacturing activities depend on the availability of electrical power. This article focuses on how production planning and scheduling can be done effectively, given prior knowledge of the high probability of an upcoming power cut occurring.

\subsection{Economic implications of load shedding}

Apart from the strain on manufacturing production planning and scheduling operations, load shedding has huge economic implications. Reports by the South African Wind Energy Association (SAWEA) [10] and the Council for Scientific and Industrial Research (CSIR) [11] revealed that it cost Eskom about R1.20 to generate every kilowatt hour of power in the year 2016. However, statistics on the cost of unserved power (in the same year - 2016) revealed that failure to generate electricity costs the South African economy more than R90 to R100 for every kilowatt hour not generated [11]. Using these figures as a basis, an energy expert [12] estimates that South Africa loses about twenty billion Rand per month for Stage 1 load shedding, forty billion Rand per month for Stage 2 load shedding, and eighty billion Rand per month for Stage 3 load shedding, as illustrated in Figure 4. 


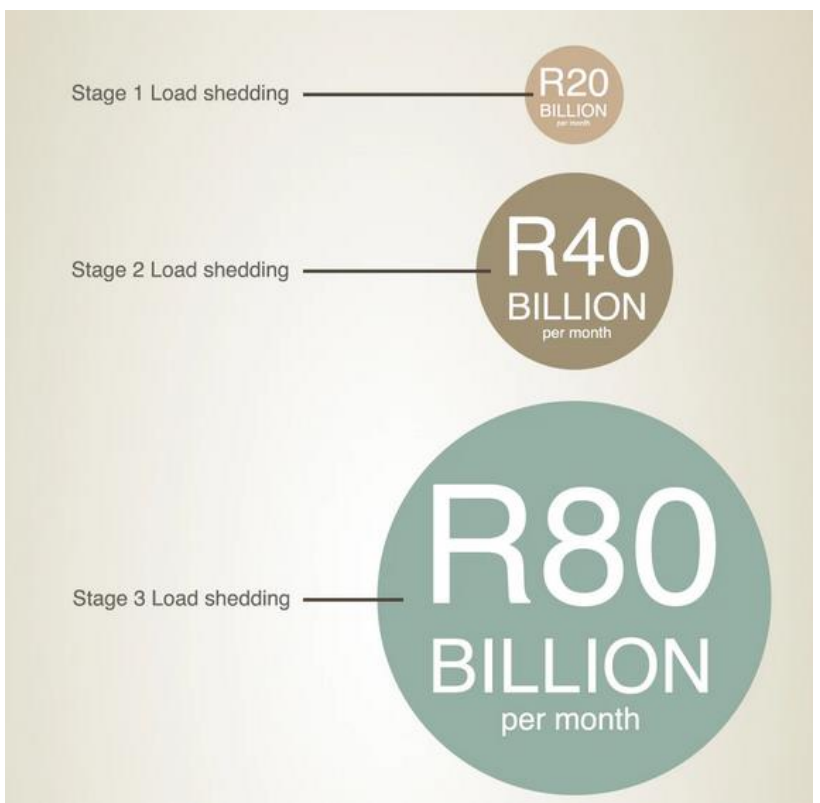

Figure 4: Cost of load shedding to South African economy [12]

These losses can be significantly reduced by the careful introduction of new ways of doing business and planning, given the current power constraints.

\subsection{Production scheduling with uncertainty}

The task of production scheduling involves assigning finite resources (usually machines and people) to competing orders over a specific time horizon to optimise some aspect of system performance. Due date conformance, or timely delivery of products, is a critical aspect of maintaining global competitiveness. To facilitate the timely delivery of customer orders, a well-prepared schedule is required. Younger [13] specified that a well-organised and carefully executed schedule is necessary to bring production through in the required quality, at the right time, and at an optimal cost. However, McCarthy and Liu [14] highlighted that there is a wide gap between scheduling theory and practice that needs addressing. Most production schedules are prepared on the assumption that they will be implemented perfectly on the shop floor. Unfortunately, shop-floor operational disturbances render a well-developed predictive schedule invalid before it is even executed by the operators on the shop floor [15]. With the frequent occurrence of operational disturbances, a new schedule, commonly known as the 'reactive schedule' must be developed [16].

In recent years, load shedding in South Africa has slowly become a common operational disturbance that cannot be ignored by any business enterprise or manufacturer. The question that remains is: Which scheduling heuristic rules must manufacturers use during production planning, given their prior knowledge of upcoming power cuts? The paper addresses this question through a field study of South African manufacturing firms, and attempts to give a road map of what local manufacturers can do, given the current power crisis.

\subsection{Dynamic scheduling approach}

Production scheduling in the face of disturbances has been called 'dynamic scheduling' [17]. Dynamic scheduling requires a different approach from static scheduling. According to Cowling and Johansson [18], the presence of real-time information about the events or operational disturbances that trigger schedule changes is the key first step to effective dynamic scheduling. There is thus a need to collect real-time information about the disturbance before it occurs. Second, the operational disturbance must be identified and classified (as predictable or unpredictable) before establishing the best way of rescheduling [17]. Selection of an appropriate rescheduling strategy is then conducted before the new (reactive) schedule is implemented. The different actions that rescheduling requires are usually documented in a rescheduling policy document, which specifies the strategy of how to revise the predictive schedule. Figure 5 summarises the steps to effective dynamic scheduling. 


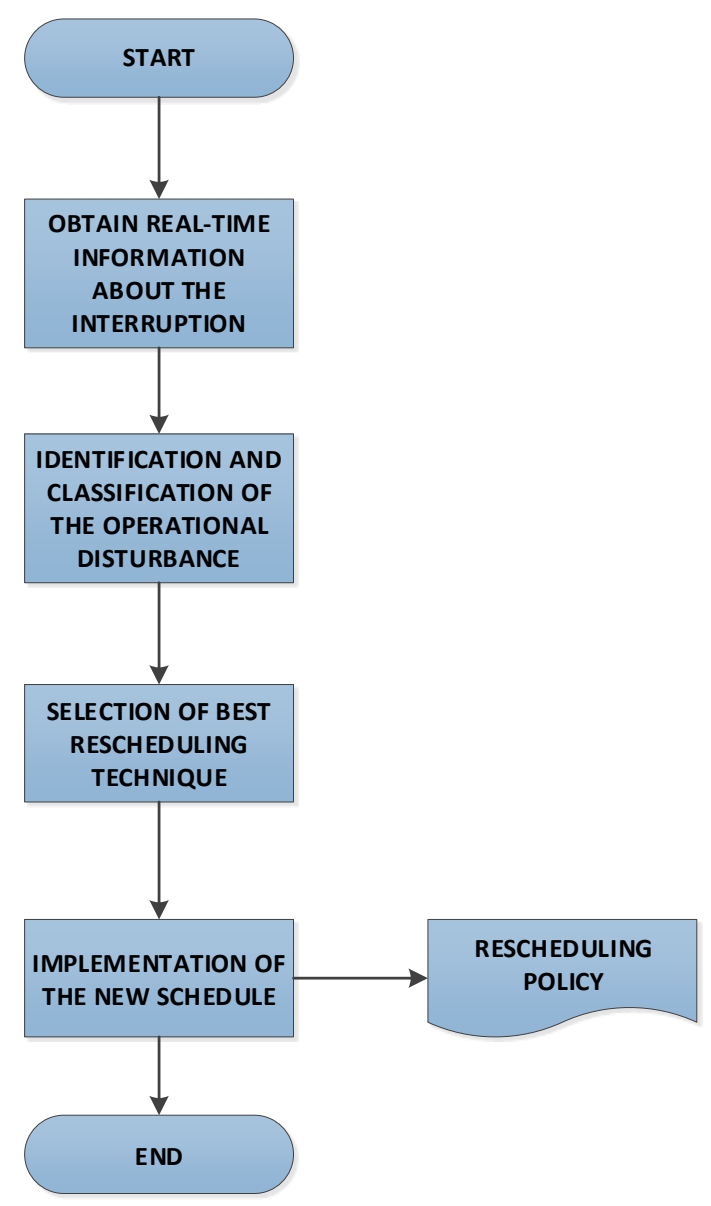

Figure 5: Dynamic scheduling steps

Different techniques to solve dynamic scheduling problems have been proposed in the literature. These include the use of heuristic sequencing rules [19], [20], [21], multi-agent systems [22], [23], expert systems [24], [25] and genetic algorithms with fuzzy logic [26], [27]. However, most manufacturing firms in South Africa employ sequencing heuristic rules for their order scheduling. This is mainly because heuristic rules are simple and easy to implement. Unlike multi-agent, fuzzy logic, or expert systems - which are computerised programs - heuristic rules can be implemented manually. This is helpful in scenarios where the planning and scheduling is conducted manually, without the use of software. A number of firms are yet to implement computerised planning and scheduling systems, making sequencing heuristic rules an ideal choice. Establishing a rescheduling policy when the disturbance is caused by power cuts - by selecting the best order sequencing rules for dynamic scheduling in scenarios of load shedding - is becoming increasingly critical.

\section{RESEARCH METHODOLOGY AND CASE STUDY}

\subsection{Research methodology}

The chosen methodology for this research was two-fold. First, a field study of manufacturing firms was conducted. The purpose of the field study was to investigate the sequencing heuristic rules that South African manufacturers use during predictive scheduling (before power cuts) and reactive scheduling (after the occurrence of power cuts). A structured questionnaire was designed and used as a method of data collection. The sampling method used was that of convenience sampling, with only forty firms in the Western Cape Province manufacturing sector selected for observation purposes. These firms were selected randomly, although most were small job-shop environments. Some of the firms agreed to take part in the study, and were visited at different times. The expert opinion method was used to select the appropriate respondents who, in this case, were shop-floor operations managers in each firm. The variables in the observation schedule questionnaire were: 
- $\quad$ Main products and process flow methods

- The key resources affected by power cuts

- $\quad$ Predictive scheduling heuristic rule employed

- $\quad$ Reactive scheduling heuristic rule employed

The Statistical Package for Social Sciences (SPSS) version 21.0 was employed for data analysis and synthesis purposes. Second, a simulation study was conducted for one of the observed firms. A simple flow-shop manufacturing firm that produces sintered car sensor rings was selected for this purpose. The purpose of the simulation study was to evaluate different heuristic rules for various load-shedding scenarios. Discrete event simulation is an essential tool for testing different scheduling strategies without affecting the realworld system [28]. The Arena 14.0 discrete event simulation package was used for this purpose.

\subsection{Case study}

The selected case study is a manufacturing firm using a semi-automated production flow-line. The firm produces powder metallurgy parts for cars, such as sensor rings, flanges, and lock and pump components. The case study focused on different orders for the sensor ring - identified as the main product. When a power cut occurs, the entire production line is stopped, and activity/work can only be restored when electricity is restored. The process flow diagram for the sensor ring fabrication process is shown in Figure 6 , while the order data used in the simulation study is shown in Table 1.

Table 1: Sensor rings order data

\begin{tabular}{|c|c|c|}
\hline Order number & Volume required & Due date \\
\hline 001 & 5 & 14 days \\
\hline 002 & 7 & 23 days \\
\hline 003 & 6 & 23 days \\
\hline 004 & 3 & 20 days \\
\hline 005 & 9 & 27 days \\
\hline
\end{tabular}

The company has eight working hours each day for five working days a week (Monday to Friday), starting at 8:00am. There are scheduled tea and lunch breaks during the working shift. The tea break is from 10:00am to $10: 15 \mathrm{am}$, while the lunch break is from 1:00pm to $1: 30 \mathrm{pm}$. Load shedding usually occurs in the morning (8:00am - 10:00am), afternoon (2:00pm - 4:00pm), or in the late afternoon (5:00pm - 7:00pm).

\section{RESULTS}

\subsection{Sample characteristics}

The sample size for the study was limited to manufacturing firms in the Western Cape province. Of the forty companies contacted, thirty agreed to take part in the study, giving a response rate of 75 per cent, which is acceptable. Table 2 presents a classification of the manufacturing firms in the study. Most of the firms observed are in the tool, die and mould-making (TDM) and plastics manufacturing industries. The mean number of employees in the observed population of companies was 23 , with a mean annual income of less than R10 million. Most of the firms are thus small, medium, or micro-enterprises (SMMEs), according to the classifications defined by the South African National Credit Regulator [29].

Table 2: Classification of number of manufacturing firms visited

\begin{tabular}{|l|c|}
\hline Category & Number of firms \\
\hline Plastics manufacturing & 8 \\
\hline Tool, die and mould-making firms & 10 \\
\hline Furniture production & 1 \\
\hline Electrical components and household appliances & 4 \\
\hline Textile and clothing industry & 3 \\
\hline Food processing firms & 4 \\
\hline Total & 30 \\
\hline
\end{tabular}




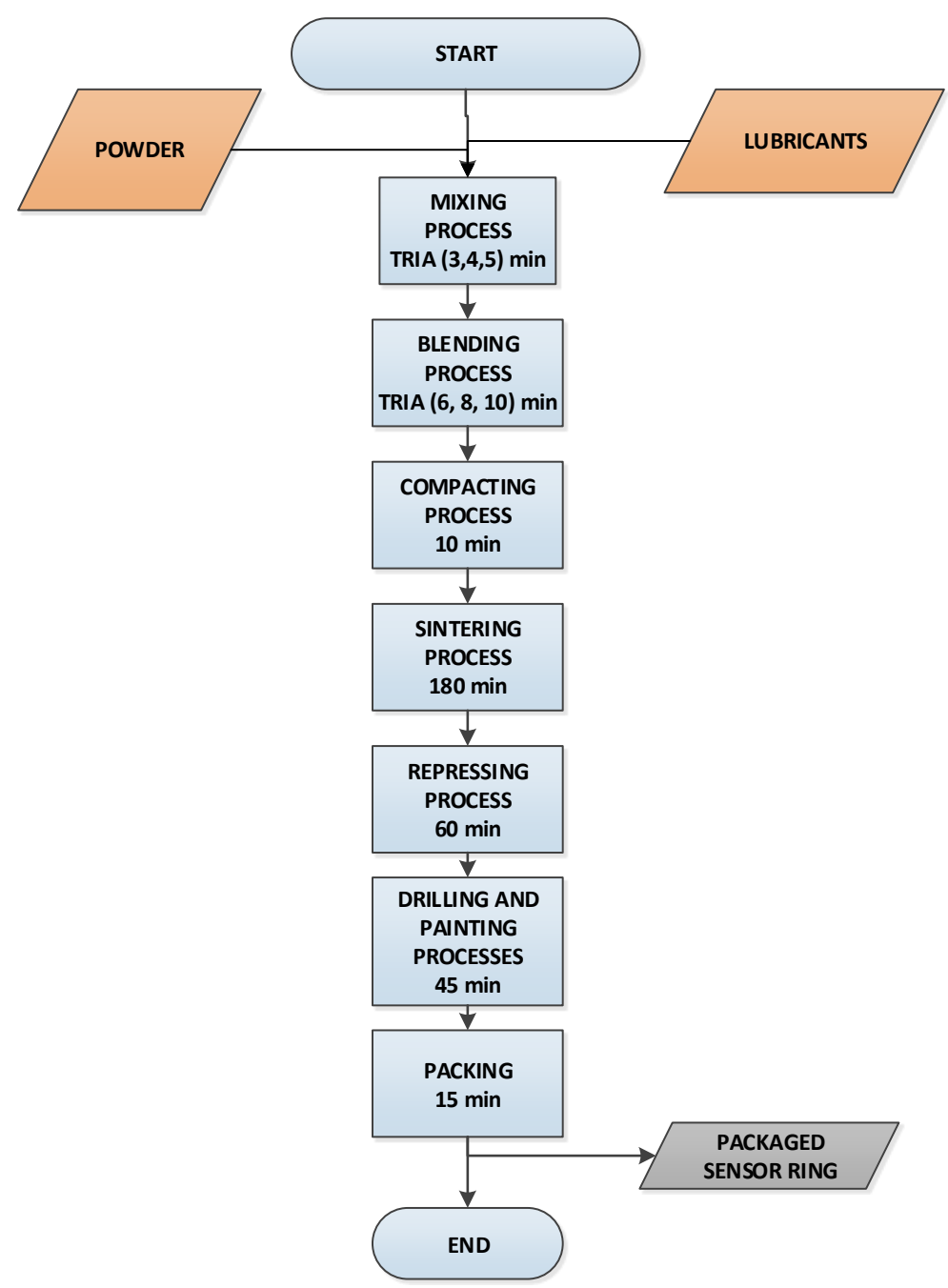

Figure 6: Process flow diagram for sensor ring fabrication

\subsection{Production scheduling heuristic rules employed}

Sequencing heuristic rules have been widely used in manufacturing firms globally owing to the simplicity of their use. These rules include approaches such as: first come, first served (FCFS), shortest processing time (SPT), earliest due date (EDD), longest processing time (LPT), critical ratio (CR), and slack time (ST) [17]. When questioned about the scheduling heuristic rules employed during predictive scheduling, most manufacturing firms indicated the use of the FCFS rule, as shown in Figure 7. Other firms indicated that they employ the EDD and SPT rules during predictive scheduling.

However, after a power cut, 69 per cent of the firms indicated that the rule used for reactive scheduling would be changed, as shown in Figure 8. Twenty-eight per cent of the firms employ the EDD rule after the power is restored to meet production due dates and to minimise the impact caused by the power cut.

\subsection{Simulation study results}

The goal of the simulation study was to select the optimal sequencing heuristic rule to use when load shedding occurs at different times of the day, with the objective of improving delivery responsiveness. Since the main objective was to minimise order delivery lateness, the maximum order tardiness and number of tardy orders were used as the key competitive measures for comparing the heuristic rules. The scheduling heuristic rules being compared were FCFS, FCLS, SPT, LPT, EDD, and LDD. The model logic for the simulation was designed using ARENA 14.0. 
Resource and schedule data stored on an external Excel spreadsheet were used for input into the simulation model. An Excel Julian calendar was used to control the different load shedding timings for three scenarios. The input and output Excel files employed are shown in Table 3 and Table 4 respectively.

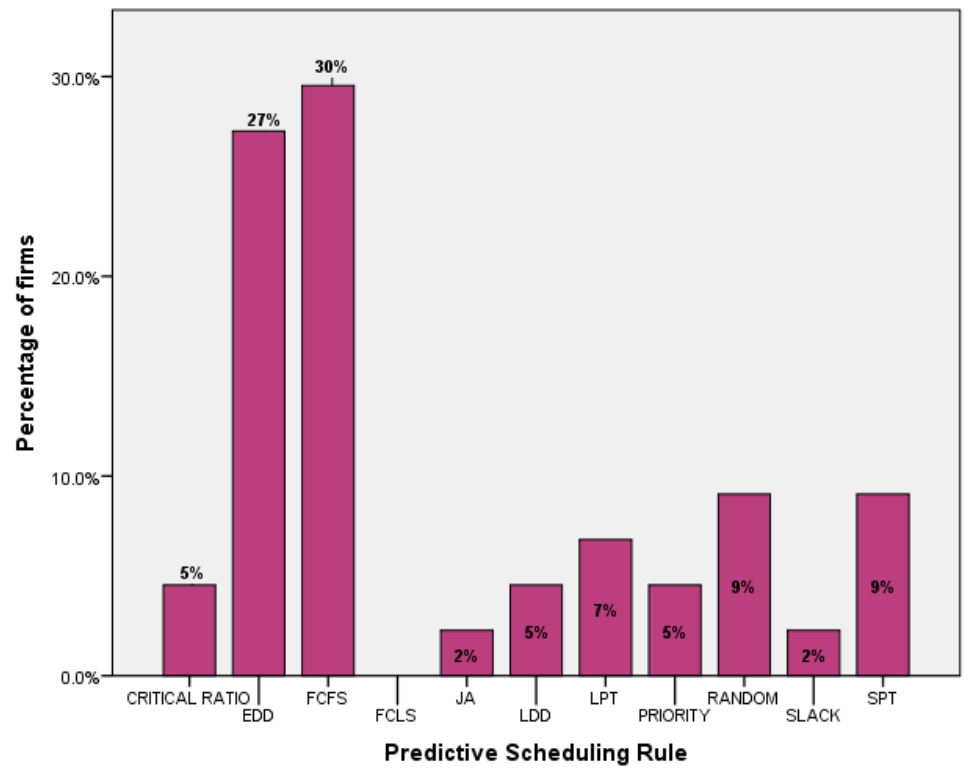

Figure 7: Heuristic rules for predictive scheduling

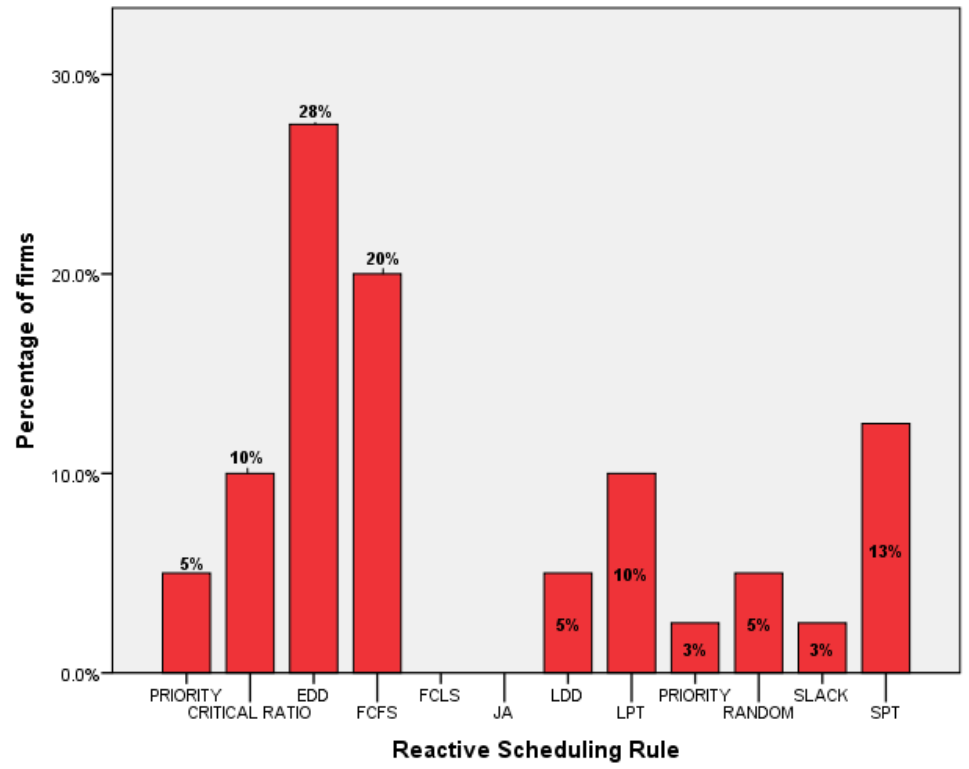

Figure 8: Heuristic rules for reactive scheduling

Table 3: Order input parameters in Excel spreadsheet

\begin{tabular}{|c|c|c|c|}
\hline Order Number & Volume & Arrival time & Due date \\
\hline 1 & 5 & $7 / 1 / 198: 00 \mathrm{AM}$ & $7 / 15 / 198: 00 \mathrm{AM}$ \\
\hline 2 & 7 & $7 / 1 / 198: 00 \mathrm{AM}$ & $7 / 24 / 198: 00 \mathrm{AM}$ \\
\hline 3 & 6 & $7 / 1 / 198: 00 \mathrm{AM}$ & $7 / 26 / 198: 00 \mathrm{AM}$ \\
\hline 4 & 3 & $7 / 1 / 198: 00 \mathrm{AM}$ & $7 / 22 / 198: 00 \mathrm{AM}$ \\
\hline 5 & 9 & $7 / 1 / 198: 00 \mathrm{AM}$ & $7 / 28 / 198: 00 \mathrm{AM}$ \\
\hline
\end{tabular}


Table 4: Resource input parameters

\begin{tabular}{|c|c|c|c|}
\hline Process & $\begin{array}{c}\text { Minimum time } \\
\text { (minutes) }\end{array}$ & $\begin{array}{c}\text { Mode time } \\
\text { (minutes) }\end{array}$ & $\begin{array}{c}\text { Maximum time } \\
\text { (minutes) }\end{array}$ \\
\hline Mixing & 3.00 & 4.00 & 5.00 \\
\hline Blending & 6.00 & 8.00 & 10.00 \\
\hline Compacting & 8.00 & 9.50 & 10.00 \\
\hline Sintering & 160.00 & 175.00 & 180.00 \\
\hline Repressing & 45.00 & 50.00 & 60.00 \\
\hline Drilling & 33.00 & 42.00 & 55.00 \\
\hline Packaging & 10.00 & 12.00 & 15.00 \\
\hline
\end{tabular}

Table 5: Summary of simulation results

\begin{tabular}{|c|c|c|c|c|c|c|c|c|}
\hline $\begin{array}{c}\text { Order } \\
\text { scheduling } \\
\text { heuristic } \\
\text { rule }\end{array}$ & \multicolumn{2}{|c|}{ No load shedding } & \multicolumn{2}{c|}{$\begin{array}{c}\text { Morning load } \\
\text { shedding } \\
(8: 00 a m-10: 00 a m)\end{array}$} & \multicolumn{2}{c|}{$\begin{array}{c}\text { Afternoon load } \\
\text { shedding } \\
(2: 00 p m-4: 00 p m)\end{array}$} & \multicolumn{2}{|c|}{$\begin{array}{c}\text { Evening load } \\
\text { shedding } \\
(5: 00 p m-7: 00 p m)\end{array}$} \\
\hline & $\begin{array}{c}\text { Maximum } \\
\text { tardiness } \\
\text { (days) }\end{array}$ & $\begin{array}{c}\text { Number } \\
\text { of tardy } \\
\text { orders }\end{array}$ & $\begin{array}{c}\text { Maximum } \\
\text { tardiness } \\
\text { (days) }\end{array}$ & $\begin{array}{c}\text { Number } \\
\text { of tardy } \\
\text { orders }\end{array}$ & $\begin{array}{c}\text { Maximum } \\
\text { tardiness } \\
\text { (days) }\end{array}$ & $\begin{array}{c}\text { Number } \\
\text { of tardy } \\
\text { orders }\end{array}$ & $\begin{array}{c}\text { Maximum } \\
\text { tardiness } \\
\text { (days) }\end{array}$ & $\begin{array}{c}\text { Number } \\
\text { of tardy } \\
\text { orders }\end{array}$ \\
\hline $\begin{array}{c}\text { FCFS } \\
\{1 ; 2 ; 3 ; 4 ; 5\}\end{array}$ & -1.9 & 2 & 35.4 & 3 & 27.2 & 3 & 11.5 & 2 \\
\hline $\begin{array}{c}\text { FCLS } \\
\{5 ; 4 ; 3 ; 2 ; 1\}\end{array}$ & 24.5 & 2 & 63.2 & 3 & 56.1 & 3 & 36.3 & 3 \\
\hline $\begin{array}{c}\text { SPT } \\
\{4 ; 1 ; 3 ; 2 ; 5\}\end{array}$ & -19.8 & 2 & 9.1 & 2 & 5.7 & 2 & -11.7 & 2 \\
\hline $\begin{array}{c}\text { LPT } \\
\{5 ; 2 ; 3 ; 1 ; 4\}\end{array}$ & 38.6 & 3 & 82.2 & 3 & 74.9 & 3 & 52.0 & 3 \\
\hline $\begin{array}{c}\text { EDD } \\
\{1 ; 4 ; 2 ; 3 ; 5\}\end{array}$ & -13 & 2 & 17.2 & 2 & 13.7 & 2 & -1.5 & 2 \\
\hline $\begin{array}{c}\text { LDD } \\
\{5 ; 3 ; 2 ; 4 ; 1\}\end{array}$ & 35.0 & 3 & 76.3 & 3 & 71.0 & 3 & 46.3 & 3 \\
\hline
\end{tabular}

Different scenarios for the power cut timings were compared for all six heuristic rules, with the best rule selected on the basis of having the lowest maximum tardiness value and the lowest number of tardy jobs. Table 5 summarises the results derived from the simulation analysis.

Results from the simulation study suggest that the shortest processing time (SPT) heuristic rule is the optimal scheduling rule to employ, since it has the lowest maximum tardiness value in all the scenarios. However, the best rule to employ depends on the type of manufacturing system employed. Different results may be obtained for manufacturing firms operating on a batch manufacturing basis from those operating on a project-oriented basis.

\subsection{Recommendations}

With the availability of information about upcoming power cuts, South African manufacturers can plan their production work ahead in a predictive manner. Using the dynamic scheduling steps illustrated in Figure 5, we recommend that manufacturers use the framework shown in Figure 9 for their process planning and scheduling.

Determination of the timing of an upcoming power cut is the first step to take before classification of the disturbance with regard to its timing. According to Carlsson and Martinsson [30], the impact of a power outage on operations depends on the time and day of the week it occurs. If the power cut occurs outside working or productive hours, its impact is minimal. Monitoring the load shedding schedule is the initial crucial step in mitigating the risk. Digital tools that facilitate this for planned load shedding are now readily available. This will help with selecting the appropriate scheduling strategy to be employed to meet certain performance criteria. 


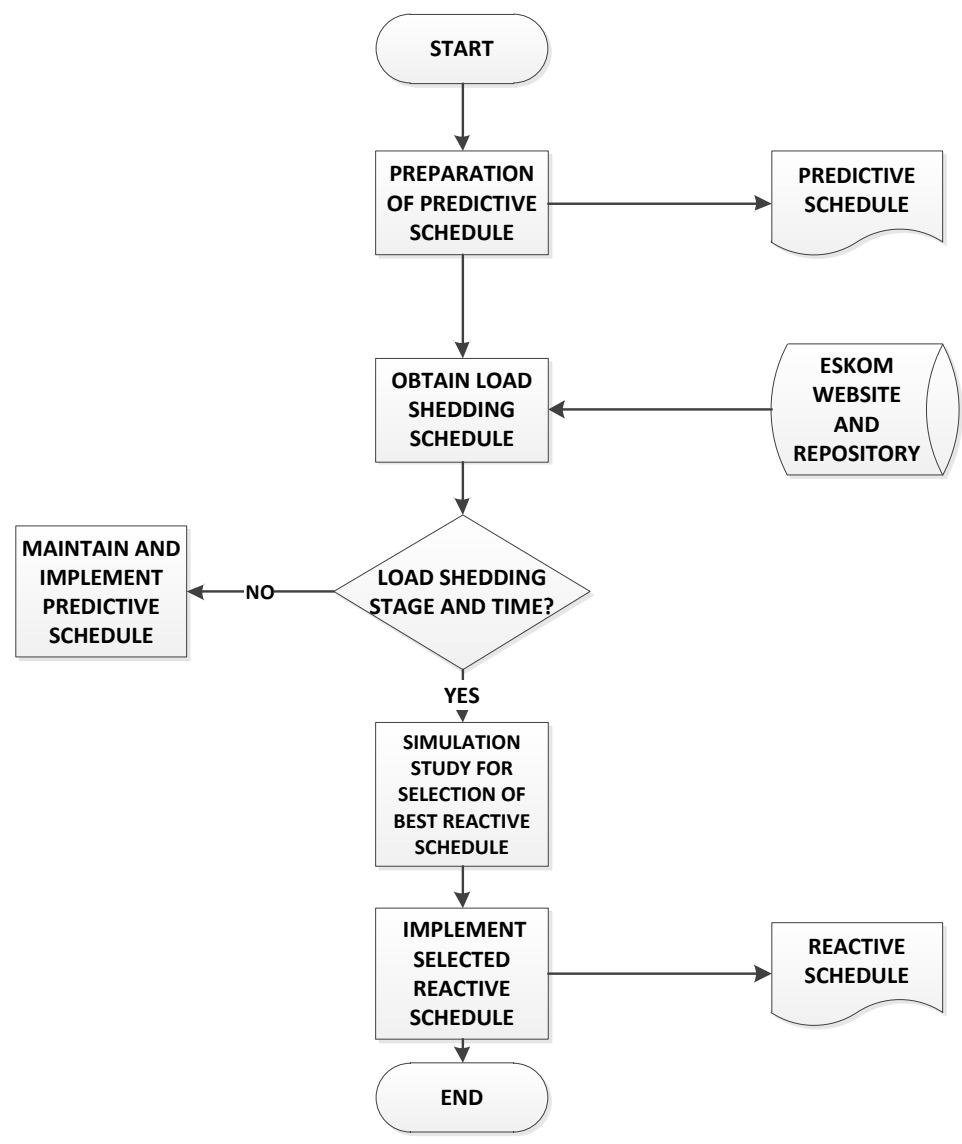

Figure 9: Proposed approach to dynamic scheduling owing to load shedding

Second, adopting flexible scheduling strategies is key during periods of power cuts. Other value-adding activities that do not depend on the availability of electricity can be scheduled during power cut periods. Myburgh [31] suggests doing activities such as board meetings, training of workers, setting up stations for the next batch, and running manually operated stations during downtime periods caused by load shedding. The plant can also reschedule maintenance tasks, tea or lunch breaks, and appraisal meetings during these downtime periods. Increasing working hours in the form of overnight shifts and weekend shifts can also help to compensate for the lost time. However, this approach can have a significant labour cost, since workers may have to be paid for overtime.

Third, some best practices to mitigate the risk associated with powercuts in manufacturing include the regular back-up of important files, the use of cloud-based solutions, and equipment protection through the use of power surge plugs. During production, important documents that facilitate the processes - such as engineering drawings, job cards, purchase orders, invoices, and work instructions - are continually developed. The regular back-up of these documents while developing them helps to avoid a scenario in which the work is lost when an outage occurs. To facilitate this, online platforms or cloud-based solutions, such as Google Drive, SharePoint, Dropbox, and Microsoft's Onedrive, can be used to store important documents that can be accessed at any time on mobile devices (even when a power cut is implemented) [32]. Furthermore, since most equipment that small manufacturers use is powered by electricity, investing in plugs that protect such machinery from surges in power is vital.

\section{CONCLUSION}

The paper has presented heuristic rules and guidelines that manufacturers can employ when a power cut is implemented. The goal of the suggested approaches is to minimise the impact or risks that the power cut can pose to the overall productivity of a firm. This risk occurs in the form of the loss of productive time, the loss of important work (such as important files), and damage to equipment. To minimise the risk of losing productive time, rescheduling activities to accommodate the power cut is vital. During Stage 1 
power cuts (the shortest duration of a power cut), work can easily be planned by simply moving downtime events such as tea or lunch breaks to periods when the power cut will occur. However, for Stages 2, 3, or 4 load-shedding periods, more productive time is lost (e.g., up to four hours for Stage 4). In such cases, the dynamic scheduling approach discussed in this paper can be employed to reschedule tasks. The risk of losing documents while they are being developed (such as invoices, drawing, and job-cards) can be minimised by the regular back-up of work, while equipment damage can be averted by investing in appliances that protect assets in case of power cuts. The use of parallel mobile systems during a power cut can also ensure progress, since some powered mobile devices can remain on for the duration of the power cut.

Eskom has consistently made the load shedding status and schedule [33] available to the South African public in the interests of communicating upcoming power cuts. Armed with this information, which alerts consumers to the load shedding stage being implemented (if any), local businesses can plan the day optimally. A temporary solution in the case of scheduled power cuts is to invest in a back-up generator. This, however, is not possible for small or start-up businesses that require substantial capital to achieve this. In the long run, a viable solution would be to explore and use greener sources of electrical energy, such as solar and wind energy. The sunshine experienced in this part of sub-Saharan Africa can make solar power a good option to consider.

Given the regular availability of the load shedding schedule online, further work can be conducted on the design of multi-agent systems to monitor upcoming power cuts and produce real-time alerts. These systems can then be extended intelligently to reschedule production activities in an autonomous manner on behalf of users. Further work can also be done to implement the results of this study during the process planning and scheduling of orders. More investigations can be carried out on different manufacturing environments, such as batch-processing or project-oriented firms. The authors suggest the use of the developed decision support framework during production planning and scheduling. The simulation model helps to determine the optimal sequencing rule in different scenarios of load shedding.

\section{REFERENCES}

[1] Statistics South Africa. 2014. P4141 Electricity generated and available for distribution. Available: http: / /beta2.statssa.gov.za/?page_id=1854\&PPN=P4141\&SCH=6139. Date accessed: 13 June 2015.

[2] Van der Nest, G. 2015. The economic consequences of load-shedding in South Africa and the state of the electrical grid, February 2015. [Online] Available:

http://www.tralac.org/discussions/article/7000-the-economic- consequences-of-load-shedding-in-south-africaand-the-state-of-the-electrical-grid.html. Date accessed: 12 July 2015.

[3] Studer R., Fensel D., Decker S. \& Benjamins, V.R. 1999. Knowledge engineering: Survey and future directions. In: Puppe F. (ed.) XPS-99: Knowledge-based systems. Survey and future directions. XPS 1999. Lecture notes in Computer Science, Vol 1570. Berlin / Heidelberg: Springer. Available: https://doi.org/10.1007/10703016_1. Date accessed: 15 June 2015.

[4] Trollip, H. 1996. Overview of the South African energy sector. Report number EG9404. Pretoria: Department of Minerals and Energy.

[5] Berger, D. 2000. South Africa year book 2000/2001. Pretoria: Government Communication and Information Services.

[6] Department of Minerals and Energy (DME). Energy balances for South Africa 1993-1998. Pretoria: DME.

[7] Statistics South Africa. 2013. Gross domestic product figures released, June 2013. [Online]. Available: http://www.statssa.gov.za/?p=903. Date accessed: 17 June 2015.

[8] Davidson, O. \& Winkler, H. 2003. South Africa's energy future: Visions, driving factors and sustainable development indicators. Report for Phase I of Sustainable Development and Climate Change Project. Energy and Development Research Centre, University of Cape Town.

[9] Department of Energy (DoE). 2013. Aggregate energy balances. Available: http://www.energy.gov.za/files/media/Energy_Balances.html. Date accessed: 17 June 2015.

[10] South African Wind Energy Association (SAWEA). 2019. The cost benefits of renewable energy (presentation). Available: https://sawea.org.za/wp-content/uploads/2019/02/RE-Costs_SAWEA2019.pdf. Date accessed: 12 January 2020.

[11] The Council for Scientific and Industrial Research (CSIR). 2017. Comments on Draft IRP 2016. Available: https://www.csir.co.za/sites/default/files/Documents/Presentation_CSIR\%20Comments\%20on\%20Draft\%20IRP201 6.pdf. Date accessed: 14 January 2020.

[12] MYBROADBAND. 2015. How much load shedding costs South Africa. 9 February 2015. [Online] Available: http: / /mybroadband.co.za/news/energy/118479-how-much-load shedding-costs-south-africa.html Date accessed: 16 June 2015.

[13] Younger, J. 1930. Work routing in production including scheduling and dispatching. New York, NY: Ronald Press Co.

[14] MacCarthy, B.L. \& Liu, J. 1993. Addressing the gap in scheduling research: A review of optimization and heuristic methods in production scheduling. International Journal of Production Research, 31, pp. 59-79. 
[15] Dewa, M.T., Matope, S., Van der Merwe, A.F. \& Nyanga, L. 2014. An empirical analysis of operational disturbances and their impact on business performance: Case tooling industry, South Africa. Proceedings of the $26^{\text {th }}$ SAlIE conference, Muldersdrift, South Africa. pp. 1-14.

[16] Aytug, H., Lawley, M.A., Mackay, K., Mohan, S. \& Uzsoy, R. 2005. Executing production schedules in the face of uncertainties: A review and some future directions. International Journal of Operational Research, 161, pp. 86110.

[17] Ouelhadj, D. \& Petrovic, S. 2009. A survey of dynamic scheduling in manufacturing systems. Journal of Scheduling, 12(4), pp. 417-431.

[18] Cowling, P. \& Johansson, M. 2002. Using real-time information for effective dynamic scheduling. European Journal of Operational Research, 139, pp. 230-244.

[19] Shafaei, R. \& Brunn, P. 1999. Workshop scheduling using practical (inaccurate) data. Part 1: The performance of heuristic scheduling rules in a dynamic job shop environment using a rolling time horizon approach. International Journal of Production Research, 37(17), pp. 3913-3925.

[20] Jain, A.K. \& Elmaraghy, H.A. 1997. Production scheduling/rescheduling in flexible manufacturing. International Journal of Production Research, 35(1).

[21] Rajendran, C. \& Holthaus, O. 1999. A comparative study of dispatching rules in dynamic flow shops and job shops. European Journal of Operational Research, 116(1), pp. 156-170.

[22] Cowling, P.I., Ouelhadj, D. \& Petrovic, S. 2004. Dynamic scheduling of steel casting and milling using multiagent systems. Journal of Production Planning and Control, 15, pp. 1-11.

[23] Ouelhadj, D., Cowling, P.I. \& Petrovic, S. 2003. Utility and stability measures for agent-based dynamic scheduling of steel continuous casting. In Proceedings of the IEEE International Conference on Robotics and Automation, pp. $175-180$.

[24] Li, H., Li, Z., Li, L.X. \& Hu, B. 2000. A production rescheduling expert system. European Journal of Operational Research,124(2), pp. 283-293.

[25] O'Kane, J.F. 2000. A knowledge-based system for reactive scheduling decision making in flexible manufacturing systems. Journal of Intelligent Manufacturing, 11(5), pp. 461-474.

[26] Rossi, A. \& Dini, G. 2000. Dynamic scheduling of flexible manufacturing systems using real-time genetic algorithms. International Journal of Production Research, 38(1), pp. 1-20.

[27] Petrovic, D. \& Duenas, A. 2006. A fuzzy logic based production scheduling/ rescheduling in the presence of uncertain disruptions. Fuzzy Sets and Systems, 157(16), pp. 2273-2285.

[28] Caggiano, A. \& Teti, R. 2014. Integration of optimisation and simulation to solve manufacturing scheduling problems. $3^{\text {rd }}$ CIRP Conference, PROCEDIA CIRP, 28, pp. 131-136.

[29] Mahembe, E. 2011. Literature review on small and medium enterprises' access to credit and support in South Africa. National Credit Regulator, pp. 1-92.

[30] Carlsson, F. \& Martinsson, P. 2008. Does it matter when a power outage occurs? A choice experiment study on the willingness to pay to avoid power outages. Energy Economics, 30(3), pp. 1232-1245. Available: http://doi.org/10.1016/j.eneco.2007.04.001. Date accessed: 20 June, 2016.

[31] FIN24. 2015. Poor loadshedding plans affect businesses, January 2015 [Online]. Available: http://www.fin24.com/Economy/Poor-load-shedding-plans-affect-businesses-20150128. Date accessed: 15 June 2015.

[32] Attaran, M. \& Woods, J. 2018. Cloud computing technology: Improving small business performance using the Internet. Journal of Small Business \& Entrepreneurship, 13(2), pp. 94-106. Available: http://doi.10.1080/08276331.2018.1466850. Date accessed: 17 November 2019.

[33] Eskom load shedding. 2020. Available: https://loadshedding.eskom.co.za/. Date accessed: 18 February 2020. 